\title{
EMPATI DAN HOMOFILI DALAM KOMUNIKASI POLITIK PEMENANGAN PEMILIHAN LEGISLATIF
}

\author{
Choirul Muna $^{1 *}$, Guntur F. Prisanto ${ }^{2}$, Niken Febrina Ernungtyas ${ }^{3}$, Irwansyah ${ }^{4}$, Sekartaji Anisa Putri ${ }^{5}$ \\ 1,2,3,5 STIKOM Inter Studi, Jl. Wijaya II No.62, Melawai, Jakarta Selatan 12160, INDONESIA \\ ${ }^{4}$ Departemen Komunikasi, Universitas Indonesia, Jl. Margonda Raya, Depok, Jawa Barat 16424, INDONESIA \\ Email: ${ }^{1}$ choirulmuna2019@gmail.com; ${ }^{2}$ guntur74@icloud.com; ${ }^{3}$ niken@ @stikom.interstudi.edu; ${ }^{4}$ ironesyah@gmail.com; \\ ${ }^{5}$ sekartajianisa@gmail.com \\ * Penulis korespondensi
}

\begin{abstract}
ABSTRAK
Komunikasi empati dan homofili dalam kampanye penting untuk menggalang dukungan masyarakat di era demokrasi. Dukungan masyarakat yang bersifat loyal dapat dicapai jika aktor politik melakukan komunikasi empati dan homofili dengan tepat. Penelitian ini bertujuan untuk mengetahui bagaimana komunikasi empati dan homofili yang dilakukan oleh Gus, seorang calon legislatif, mampu meraih suara dari sebuah komunitas yang pada dasarnya apatis terhadap politik, yaitu jama'ah thoriqoh. Metode penelitian yang digunakan adalah pendekatan kualitatif, dengan teknik pengumpulan data wawancara mendalam dan observasi. Hasil penelitian menunjukkan bahwa komunikasi empati dan homofili yang dilakukan Gus, menjadikannya dipandang sebagai bagian jama'ah thoriqoh itu sendiri sehingga meningkatkan kredibilitasnya. Aspek homofili yang dipenuhi oleh Gus sehingga mendapatkan dukungan penuh yang loyal dari jama'ah thoriqoh ialah dari segi kesamaan dalam berpakaian, beragama, bertutur kata, bersikap, dan dalam melaksanakan ritual.
\end{abstract}

Kata kunci: Empati; Homofili; Jama’ah Thoriqoh; Komunikasi Politik.

\begin{abstract}
Empathy and homophily communication in campaigns is important to garner public support in the era of democracy. Loyal community support can be achieved if political actors make empathy and homophile communication appropriately. This study aims to find out how empathy and homophile communication carried out by Gus, a legislative candidate, is able to win votes from a community that is basically apathetic to politics, namely the thoriqoh congregation. The research method used is a qualitative approach, with in-depth interview and observation data collection techniques. The results showed that the communication of empathy and homophilia carried out by Gus, made it seen as part of the Thoriqoh congregation itself thus increasing its credibility. The homophile aspect fulfilled by Gus so that he gets full loyal support from the Thoriqoh congregation is in terms of equality in dressing, religion, speaking, behaving, and in carrying out rituals.
\end{abstract}

Keywords: Empathy, Homophily, Political Communication, Thoriqoh Congregation.

\section{PENDAHULUAN}

Komunikasi empati dan homofili penting untuk menggalang dukungan ketika aktor politik terlibat dalam kontestasi pemilihan umum. Berbagai negara yang menganut sistem demokrasi melibatkan warga negara dalam pemilihan pemimpin melalui kotak suara (Mohammad, 2007). Agar sukses memperoleh suara, komunikasi homofili digunakan demi dapat mengontrol opini publik. Memiliki kontrol atas opini publik menjadi hal yang penting demi mencapai kemenangan politik (Indrayani, 2009). Para politikus maupun pemimpin dunia mengenal komunikasi homofili atau kesamaan yang menjadi begitu populer untuk diterapkan di lapangan. Komunikasi homofili tersebut banyak digunakan oleh aktor politik dan pemerintah demi menyukseskan karir politik mereka (Maoz, 2012). Pendekatan politik menggunakan kon- sep homofili tidak hanya dilakukan oleh para aktor politik kepada masyarakat saja, namun juga kepada sesama aktor politik maupun pemerintah. Para politikus cenderung berhubungan dan bekerja sama dengan rekan politik yang memiliki kesamaan nilai maupun latar belakang dengan diri mereka (Korainen et al., 2019; Opper et al., 2015). Hal tersebut dipercaya akan memudahkan penyelesaian pekerjaan serta meningkatkan karir mereka.

Perbedaan kelas sosial antara sesama aktor politik maupun dengan masyarakat dapat dijembatani dengan homofili. Homofili dalam hal budaya dapat menyatukan individu dari kelas sosial yang berbeda (Basov, 2019). Maka itu, aktor-aktor politik yang sukses menggunakan teknik homofili secara tidak sadar dianggap sebagai bukan aktor politik oleh para pemilihnya. Sebagaimana kasus Donald Trump yang 
dianggap bukan politikus oleh sebagian besar rakyat Amerika (Agnew \& Shin, 2016). Hal tersebut menunjukkan berhasilnya Trump dalam menjalankan strategi komunikasi politik homofili. Selain dilakukan melalui komunikasi tatap muka, strategi homofili juga banyak digunakan di media sosial. Homofili dalam internet maupun media sosial oleh pengguna (Farrel, 2012) dapat menciptakan sebuah ruang yang menggaungkan kesamaan pilihan politik (Colleoni et al., 2014). Sehingga dapat mengumpulkan kelompok massa pendukung secara virtual.

Salah satu fenomena yang menarik diamati di kancah politik Indonesia adalah terpilihnya Gus, Caleg DPR RI dalam pemilu legislatif tahun 2014 Daerah Pemilihan Jawa Tengah 6 dari Partai Nasional Demokrat dengan menggunakan strategi komunikasi empati dan homofili. Walaupun Gus merupakan pendatang baru dalam kontestasi politik nasional, namun Gus berhasil menjadi anggota DPR RI dengan perolehan suara lebih dari 71.000 suara. Perolehan suara yang mengantarkannya menjadi anggota legislatif ini patut menjadi perhatian dalam kajian komunikasi politik, karena Partai Nasional Demokrat pun merupakan partai baru dalam kancah politik nasional. Basis utama pemilih yang menjadi target sasaran utama Gus adalah jama'ah thoriqoh Kabupaten Magelang dan Wonosobo. Salah satu kelompok masyarakat yang memiliki basis atau jumlah pengikut yang banyak di Indonesia adalah jama'ah thoriqoh. Setiap kelompok thoriqoh memiliki pengikut yang banyak mulai dari ratusan hingga ribuan jama'ah.

Jama'ah thoriqoh di Indonesia memiliki basis massa dan jaringan yang kuat. Jama'ah thoriqoh juga memiliki pandangan ideologi yang hampir sama antar masing-masing jama'ah. Bahkan kesamaan ideologi tersebut mencakup hampir seluruh aspek kehidupan. Baik dari segi keagamaan, ekonomi dan politik mereka memiliki pandangan yang hampir sama. Meskipun jama'ah thoriqoh sangat tertutup dan agak tabu membicarakan politik, Gus mampu meraih dukungan dari lingkungan jama'ah thoriqoh dalam pemilu legislatif 2014.

Selama masa kampanye dan bahkan dalam keseharian, Gus selalu berinteraksi dengan lingkungan jama'ah thoriqoh yang membuat Gus diterima sebagai representasi dari lingkungan jama'ah thoriqoh. Bagaimana komunikasi empati dan homofili yang dilakukan Gus sebagai seorang calon anggota legislatif di lingkungan jama'ah thoriqoh akan menjadi perhatian utama dalam penelitian ini. Selanjutnya penelitian ini bertujuan untuk menggali bagaimana persepsi jama'ah thoriqoh atas komunikasi empati dan homofili yang dilakukan calon anggota legislatif, terutama dalam kaitannya dengan perilaku pemilih dalam pemilihan legislatif.

\section{KAJIAN LITERATUR}

Arifin (2011) menyatakan bahwa berdasarkan paradigma komunikasi politik dapat diuraikan empat teori dasar dalam komunikasi politik. Salah satunya adalah teori empati dan teori homofili, sebagaimana diperkenalkan Rogers dan Shoemaker sebagai penjabaran dari paradigma interaksional. Empati adalah komunikasi emosi afektif atau sentimen antara orang-orang yang terjadi melalui pengambilan perspektif. Berempati dengan orang lain adalah memahami dalam sebuah cara yang menggabungkan perasaan dan pengertian, perspektif afektif-kognitif mereka. Empati dipahami sebagai kendaraan untuk komunikasi emosi, tetapi tidak tanpa konten intelektual. Empati adalah bentuk pemahaman yang menggabungkan perasaan dengan pikiran. Emosi yang dikomunikasikan merupakan campuran pengaruh dan kognisi. Dipahami dengan cara ini, jelas bahwa empati melibatkan integrasi hati dan pikiran daripada emosionalisme sederhana (Krausse, 2011).

Scudder (2016) menyatakan bahwa dengan pergantian arah dalam teori demokrasi menjadi demokrasi deliberatif, muncul penekanan baru pada empati. Empati sering disebut sebagai kapasitas emosional yang penting untuk keberhasilan dan peningkatan wacana demokratis. Teori demokratik kontemporer telah mengantarkan pada model yang "talk centric" daripada "vote centric". Menurut model demokrasi deliberatif, legitimasi keputusan sebagian besar tergantung pada kualitas diskusi dan musyawarah yang mendahului pemungutan suara. Dengan kata lain, kualitas demokratis meningkat melalui interaksi komunikatif yang adil dan inklusif di antara warga negara. Empati dipandang sebagai salah satu dari sedikit "emosi yang baik" sesuai dengan wacana rasional dan argumentasi yang beralasan. Pendukung empati berargumentasi bahwa empati yang lebih besar di antara warga akan mempertahankan legitimasi demokratis dengan mendorong inklusivitas dalam komunikasi politik.

Menurut Fouke (2009) dalam literatur psikologi saat ini terdapat perhatian yang meningkat pada fungsi kognitif dan dasar neurologis empati. Pada tingkat pengalaman, konstruksi psikologis ini menunjukkan kesamaan rasa antara perasaannya sendiri dan yang diungkapkan oleh orang lain. Pada tingkat dasar des- 
kripsi, empati bisa dipahami sebagai interaksi antara dua individu, dimana seseorang mengalami dan berbagi perasaan yang lain (Decety \& Jackson, 2006). Kapasitas emosional ini diperlukan untuk membangun diskursus publik yang rasional dalam demokrasi deliberatif. Plesca (2013) menekankan bahwa selama proses musyawarah (deliberasi), empati dibutuhkan untuk membangun komunikasi politik yang efektif. Komunikasi politik dengan tujuan membujuk orang lain, berdasarkan solidaritas dan kekuatan argumen pribadi, pertama-tama orang harus mendengarkan, memahami, dan dengan jujur menerima nilai dari argumen orang lain.

Rogers dan Shoemaker (dalam Kuppelwieser \& Touzani, 2016) menyatakan bahwa anggota sistem sosial, seperti teman atau teman sebaya, cenderung memiliki karakteristik sosio-demografi dan atribut perseptual, seperti keyakinan dan sikap, yang serupa. Berdasarkan pemahaman Rogers dan Shoemaker, terdapat apa yang disebut dengan homofili, yang merupakan variabel obyektif. Jika orang memiliki asal-usul atau kebiasaan yang sama, maka mereka dianggap homophilous.

Pemahaman tentang homofili ini menjadi penting ketika dikaitkan dengan perilaku masyarakat untuk memperoleh informasi politik. Dalam masyarakat modern, sebagian besar individu bergantung pada orang lain untuk memperoleh sebagian besar informasi politik mereka. Bukti empiris tentang pentingnya berbagi informasi politik dalam mempengaruhi perilaku pemilih individu, kembali pada tahun 1950an ketika melalui serangkaian percobaan lapangan, sosiolog Universitas Columbia, Paul F. Lazarsfeld dan rekan-rekannya mendokumentasikan keunggulan interaksi tatap muka dalam menyebarkan informasi politik dan menunjukkan bahwa informasi lebih mungkin menjangkau pemilih yang ragu-ragu (Galeotti \& Mattozzi, 2011).

Komunikasi antarpribadi terjadi lebih sering di antara individu yang secara ideologis serupa. Ini adalah bentuk yang sangat sederhana dari apa yang disebut "nilai homofili", sebagaimana formulasi orisinal dari Lazarsfeld dan Merton (1954). Homofili dalam konteks komunikasi politik mengacu pada situasi dimana frekuensi komunikasi interpersonal antar pemilih tergantung pada kesamaan ideologis. Homofili murni menggolongkan kelompok masyarakat di mana tautan komunikasi hanya aktif dalam kelompok-kelompok ideologis yang homogen. Dalam pengertian ini, tingkat homofili juga dapat diartikan sebagai tingkat pemisahan antara kelompok-kelompok ideologis homogen yang berbeda (Galeotti \& Mattozzi, 2011).
Selanjutnya kajian Galeotti dan Mattozzi (2011) menyatakan bahwa terlepas dari peran dominan media massa dalam periklanan politik, penelitian empiris beberapa tahun terakhir menunjukkan bahwa komunikasi dari mulut ke mulut (word of mouth) masih merupakan masukan yang mendasar bagi proses pembelajaran pemilih. Misalnya, dalam studi empiris tahun 1992 dalam kampanye pemilihan presiden Amerika, Paul Allen Beck et al (2002) menyimpulkan bahwa diskusi dan perbincangan interpersonal lebih besar pengaruhnya daripada media dalam mempengaruhi perilaku memilih. Kredibilitas sumber pada proses komunikasi dari mulut ke mulut (word of mouth), memiliki pengaruh signifikan, sebagaimana dinyatakan McLaughlin (2012). Menurutnya, terdapat tiga komponen kredibilitas sumber informasi: keahlian, kepercayaan dan disukai; dimana masing-masing memiliki peran yang berbeda. Homofili dieksplorasi sebagai komponen kredibilitas sumber, sehingga sumber informasi akan lebih disukai.

Penelitian tentang ketidaksepakatan politik dalam jaringan komunikasi oleh Huckfeldt, Johnson, dan Sprague (2004) mengamati bahwa pemilih yang demokratis terdiri dari pengambil keputusan yang saling bergantung secara individual dan politis. Mereka bergantung satu sama lain untuk informasi dan panduan politik. Juga terdapat bukti bahwa komunikasi antarpribadi terjadi lebih sering di antara individu yang secara ideologis serupa, sebagaimana didokumentasikan oleh McPherson, Smith-Lovin dan Cook (2001). Pemilih dapat mempelajari informasi dengan secara langsung menerima iklan informatif dari pihak-pihak lain (paparan langsung) serta berbicara tentang politik dengan pemilih lain (paparan kontekstual) (Galeotti \& Mattozzi, 2011).

Komunikasi politik pada akhirnya bersifat personal. Bagi Voicu (2013) tindakan komunikasi memiliki efek untuk mempengaruhi orang lain untuk percaya, berpikir atau bertindak. Komunikasi berarti seseorang yang membentuk dirinya sendiri, terbuka untuk yang lain dengan kata, tanda dan pendekatan relasional. Kemampuan mempengaruhi adalah sumber daya dari seseorang dan keterampilan sebagaimana untuk memotivasi orang lain, yaitu untuk membuat mampu berpikir atau bertindak dalam arah yang diinginkan. Lebih lanjut Voicu (2013) menyatakan bahwa tindakan komunikasi selalu memiliki identitas. Tindakan komunikasi mengedepankan ekspresi identitas tersebut. Dalam konteks komunikasi politik, seorang politisi dapat berkomunikasi hanya jika menempatkan diri sendiri dan diakui dalam posisi tersebut dan merancang bagaimana tindakan komunikatifnya berhubungan dengan keberadaannya secara sosial. 
Sementara Bratu (2013) menyatakan bahwa politisi harus berkomunikasi dengan konstituen mereka dengan menunjukkan sedemikian rupa sehingga mereka mengganggap politisi memiliki kepedulian. Kepercayaan dan rasa suka pada kandidat politik memiliki hubungan positif yang signifikan dengan persepsi pemilih tentang kredibilitas kandidat. Politisi yang efektif terampil dalam perilaku yang dirancang untuk menciptakan citra yang diinginkan. Niat baik adalah karakteristik penting dari kandidat politik dalam benak pemilih. Komunikasi empati dan homofili menjadi penting untuk merebut hati masyarakat yang diaplikasikan melalui kampanye. Kampanye merupakan sebuah kegiatan yang memiliki pengaruh pengaruh besar kepada masyarakat yang paling tidak sadar akan kegiatan politik (Claassen, 2011).

Berempati, menjadi bagian dari masyarakat pemilih dan memberikan arah dan bahkan menciptakan kehendak masyarakat membutuhkan kemampuan komunikasi politik yang lebih dari rata-rata. Ditambah lagi, mengacu pada Egidi (2017) membutuhkan kemampuan untuk membujuk atau persuasi. Namun terkait persuasi Ariton-Gelan (2015) memberikan catatan, bahwa sebagai bentuk perilaku manusia, persuasi mengandung potensi masalah moral yang membutuhkan pilihan sadar tentang tujuan dan caracara untuk mencapai retorika yang disampaikan. Dalam proses persuasi dibutuhkan penilaian obyektif, baik dari pelaku persuasi (persuasive agent), penerima pesan maupun pengamat independen. Tanggung jawab etis dari pelaku persuasi atau orang-orang yang membujuk, berasal dari status atau posisi sosial dimiliki, dalam tugas yang mereka lakukan (janji, komitmen yang sungguh-sungguh, perjanjian) atau dalam konsekuensi (efek) dari tindakan komunikasinya (Ariton-Gelan, 2015).

Selanjutnya Ariton-Gelan (2015) menekankan bahwa ketika berbicara tentang orang yang mempersuasi, dalam situasi argumentatif dan persuasif, terdapat kewajiban moral untuk memeriksa validitas bukti dan argumen sebelum menyajikannya kepada orang lain. Persuasi harus ditafsirkan sebagai transaksi dimana pelaku persuasi dan penerima pesan yang dibujuk memiliki tanggung jawab bersama, yaitu untuk berpartisipasi aktif dalam proses. Larson menyatakan bahwa penerima pesan sebagai pihak yang dibujuk, memikul tanggung jawab lebih, yang diekspresikan dengan umpan balik yang memadai dan skeptisisme moderat. Jika teknik persuasi ternyata merongrong kepercayaan dan keyakinan yang diperlukan untuk membuat keputusan publik yang akurat, maka dapat dikategorikan sebagai tindakan komunikasi yang tidak etis. Umpan balik yang memadai membutuhkan hubungan yang mencerminkan tingkat pemahaman, opini, perasaan, dan penalaran yang memadai dan jujur.

\section{METODE PENELITIAN}

Penelitian ini adalah penelitian deskriptif kualitatif yang didasarkan pada fenomena, gejala, fakta, atau informasi sosial. Pendekatan ini dapat diartikan sebagai penelitian yang ingin mengetahui lebih detail lagi mengenai suatu masalah yang dipilih, untuk menangkap aspek-aspek dalam dunia sosial yang sangat sulit dijelaskan dengan angka-angka. Pemilihan pendekatan dilakukan dengan pertimbangan pada permasalahan yang hendak ditelusuri lebih lanjut dalam penelitian. Menurut Bogdan dan Taylor pendekatan kualitatif diharapkan mampu menghasilkan suatu uraian mendalam tentang ucapan, tulisan dan atau perilaku yang dapat diamati dari suatu individu, kelompok, masyarakat dan atau organisasi tertentu dalam suatu konteks tertentu yang dikaji dari sudut pandang yang utuh, komprehensif dan holistik (Moleong, 2017).

Penelitian ini merupakan penelitian etnografi yang mengambil data melalui observasi dan wawancara mendalam. Wawancara mendalam dilakukan kepada kyai pengasuh pesantren An-Nawawi Berjan dan seorang jama'ah thoriqoh. Informan dalam penelitian ini seluruhnya menganut thoriqoh qodriyah wa naqsabandiyah. Pesantren An-Nawawi Berjan terletak di kota Purworejo. Wawancara mendalam ini ditopang dengan observasi untuk mengetahui bagaimana respon komunitas jama'ah thoriqoh terhadap komunikasi politik yang diterapkan oleh calon anggota legislatif. Penulisan hasil wawancara dilakukan setelah proses wawancara. Tahap ini dilakukan dengan membuat transkrip berdasarkan wawancara. Proses analisis data dalam penelitian kualitatif dilakukan setelah pengumpulan data selesai dari masing-masing informan. Dalam proses analisis data, aspek-aspek pembentuk homofili yang ditemukan dari hasil observasi dan wawancara akan disederhakan ke dalam tabel. Kemudiaan temuan akan dibahas berdasarkan hasil kajian literatur.

\section{HASIL DAN PEMBAHASAN}

Berdasarkan hasil penelitian melalui wawancara kepada sejumlah informan, diperoleh data bahwa caleg Gus memiliki lima aspek homofili dengan jama'ah thoriqoh seperti yang ada pada tabel di bawah ini: 
Tabel 1. Temuan Aspek Homofili

\begin{tabular}{clc}
\hline No. & \multicolumn{1}{c}{ Aspek Homofili } & $\begin{array}{r}\text { Aspek Homofili Gus dengan } \\
\text { Jama'ah Thoriqoh }\end{array}$ \\
\hline 1 & Pakaian & $\mathrm{V}$ \\
2 & Agama & $\mathrm{V}$ \\
3 & Tutur Kata & $\mathrm{V}$ \\
4 & Sikap & $\mathrm{V}$ \\
5 & Ritual & $\mathrm{V}$ \\
6 & Orientasi Politik & - \\
7 & Pemasukan Ceramah & - \\
\hline Keterangan: V (ada kesamaan) & - (tidak ada kesamaan)
\end{tabular}

Keterangan: V (ada kesamaan), - (tidak ada kesamaan)

Dalam melakukan kampanye di lingkungan jama'ah thoriqoh, Gus dinilai melakukan dengan sepenuh hati oleh para informan. Seperti informan AK menyatakan "ya sepanjang yang saya ketahui ya positif, negatifnya tidak ada." Penerapan aspek homofili oleh Gus mendapatkan respon positif dari para informan yang merupakan bagian dari pengurus jama'ah thoriqoh.

Dari sisi pakaian, Gus mengenakan pakaian putihputih dan peci putih yang menjadi ciri khas dari jama'ah thoriqoh. Dalam berbagai kesempatan berkunjung, Gus memakai pakaian yang serupa dengan pakaian yang digunakan oleh Jama'ah thoriqoh. Kesamaan lainnya yang juga membangun aspek homofili Gus dengan Jama'ah thoriqoh ialah kesamaan agama yang dipercayai. Tak luput juga ritual seperti wirid dan pengajian rutin tak pernah dilewatkan oleh Gus. Kapanpun Gus diundang untuk mengisi pengajian atau kegiatan lain dari jama'ah thoriqoh, ia selalu menyempatkan untuk hadir. Perilaku ini menjadikan Gus menyatu dengan jama'ah thoriqoh. Ia dianggap sama dengan komunitas tersebut. Adanya kebiasaan yang sama dan tercipta antara Gus dengan Jama'ah thoriqoh merupakan aspek pembentuk homophilous sebagaimana dinyatakan Rogers dan Shoemaker (1971).

Berdasarkan hasil observasi dalam penelitian ini, tak jarang pula Gus diminta untuk memberikan tausiyah atau ceramah pada komunitas tersebut. Namun ada hal yang berbeda dari Gus dengan Kyai atau pemuka agama lainnya dalam hal pemasukan ceramah. Jika Kyai lain mendapatkan "sangu" berupa uang dalam amplop setelah selesai memberikan ceramah kepada para jama'ah, Gus justru tidak menerimanya. Ia berinisiatif meninggalkan sejumlah uang sebagai bentuk solidaritas pada penyelenggara acara, dengan maksud menyumbang untuk membeli gula, kopi atau makanan kecil yang dihidangkan untuk para tamu.

Pada kesempatan-kesempatan mengisi ceramah maupun berkumpul dengan jama'ah thoriqoh, Gus memanfaatkan momen tersebut untuk membangun sikap yang sama dengan jama'ah thoriqoh. Sikap yang disenangi dan dinjunjung dalam jama'ah thoriqoh ialah lebih banyak mendengarkan dan memahami, yang berkaitan dengan empati. Sehingga dalam pelbagai acara, Gus lebih banyak mendengarkan dan memahami persoalan-persoalan yang berkembang di tengah jama'ah thoriqoh. Gus dalam bertutur kata tidak banyak mengumbar janji, namun lebih banyak memohon doa restu dan dukungan pada jama'ah thoriqoh. Ia memohon doa agar diberikan amanah untuk dapat duduk sebagai wakil rakyat, sehingga memiliki kewenangan yang memadai untuk membantu persoalan-persoalan dalam jama'ah thoriqoh.

Gus memahami bahwa jama'ah thoriqoh sebagai penerima pesan, adalah orang-orang yang rendah hati. Mengumbar janji dapat dimaknai sebagai perilaku yang arogan. Karena itu ia memilih untuk lebih banyak mendengar dan menyerap kegelisahan maupun keinginan masyarakat. Gus menjadikan komunikasi politik dalam kampanye sebagai sebuah proses yang deliberatif, berbasis empati yang dibutuhkan untuk membangun komunikasi politik yang efektif, sebagaimana temuan Plesca (2013). Komunikasi politik dengan tujuan membujuk orang lain, berdasarkan solidaritas dan kekuatan argumen pribadi, pertamatama orang harus mendengarkan, memahami, dan dengan jujur menerima nilai dari argumen orang lain.

Kemampuan Gus untuk dipersepsikan sebagai bagian dari jama'ah thoriqoh ditindaklanjuti dengan komunikasi yang intensif untuk memperbincangkan persoalan-persoalan agama dan kenegaraan. Langkah ini menjadi strategis mengingat pemahaman tentang homofili menjadi penting ketika dikaitkan dengan perilaku masyarakat untuk memperoleh informasi politik. Dalam masyarakat modern, sebagian besar individu bergantung pada orang lain untuk memperoleh sebagian besar informasi politik mereka. Interaksi tatap muka memiliki keunggulan dalam menyebarkan informasi politik dan menunjukkan bahwa informasi lebih mungkin menjangkau pemilih yang ragu-ragu (Galeotti \& Mattozzi, 2011).

Pilihan Gus untuk menjadikan jama'ah thoriqoh sebagai target utama pemilih, didasari alasan bahwa ia ingin membangun relasi politik yang berbasis kedekatan personal. Ia tidak mau terjebak dalam politik yang transaksional. Sehingga dengan ia mendekatkan diri, berperilaku sama, serta berpakaian serupa; Gus hendak menjadikan dirinya sebagai "orang dalam" bagi jama'ah thoriqoh. Gus memiliki pandangan, bahwa apabila ia diterima sebagai bagian dari jama'ah thoriqoh, maka kredibilitasnya sebagai calon anggota 
legislatif akan meningkat. Pernyataan-pernyataan yang merupakan sikap politiknya akan lebih diterima oleh jama'ah thoriqoh. Temuan ini menunjukkan bahwa homofili berdampak pada tingkat kredibilitas individu, yaitu semakin besar tingkat kesamaan yang dimiliki maka kredibilitas individu dan peluang untuk terciptanya kerjasama akan semakin tinggi (Opper et al., 2015; Housholder \& LaMarre, 2014). Hal tersebut juga sejalan dengan temuan McLaughlin (2012) yang menyatakan bahwa kredibilitas sumber pada proses komunikasi, memiliki pengaruh signifikan.

Komunikasi empati dan homofili yang dilakukan oleh Gus juga berdampak pada pembiayaan politik yang menjadi bebannya. Biaya tetap harus dikeluarkan sebagai bagian dari realitas politik. Namun biaya tersebut relatif kecil dibandingkan para kandidat lain, utamanya sesama politisi yang belum pernah terpilih sebagai anggota legislatif. Biaya yang dikeluarkan tersebut lebih dirasakan sebagai bagian dari silaturahmi daripada biaya untuk "membeli suara". Kebutuhan finansial yang dikeluarkan diantaranya untuk memenuhi permintaan membeli piring atau gelas, yang menjadi kebutuhan ketika jama'ah thoriqoh menyelenggarakan aktivitas religi, seperti pengajian. Temuan bahwa homofili terkait dengan reduksi suatu biaya yang diperlukan juga ditemukan dalam penelitian Gerber et al. (2013). Kesamaan-kesamaan yang ada antara satu pihak dengan pihak lain dalam dunia pekerjaan dapat berdampak positif pada pengurangan beban pengeluaran.

Pilihan Gus untuk menjadikan jama'ah thoriqoh sebagai kantong suara, disadari atau tidak, adalah pilihan yang cermat. Sebagai komunitas yang perhatian utamanya adalah upaya mendekatkan diri pada Allah SWT, jama'ah thoriqoh tidak terlalu menaruh perhatian pada politik. Namun justru komunitas ini yang berpotensi terdampak paling besar secara politik. Sebagaimana beberapa ahli menemukan bahwa efek kampanye yang lebih besar adalah bagi mereka yang paling tidak sadar politik/ the least politically aware (Claassen, 2011). Banyak mendengar, bersikap rendah hati, hormat pada mursyid dan berperilaku sama seperti jama'ah thoriqoh adalah kunci keberhasilan Gus dalam meraih kepercayaan mereka. Berdasarkan hal di atas, jama'ah thoriqoh merasa tidak ada lagi jarak dengan Gus, karena telah dipandang sebagai bagian dari jama'ah thoriqoh itu sendiri. Jama'ah thoriqoh yang memandang Gus sebagai bagian dari mereka kemudian memercayakan pilihan dan langkah-langkah politik mereka kepada Gus.
Di sisi lain, jama'ah thoriqoh merasa bahwa komunikasi politik yang dilakukan Gus berbeda dari para calon anggota legislatif lainnya. Pendekatan yang dilakukan Gus dinilai santun, nglaras, tidak terburuburu seperti orang yang hanya mementingkan urusan pribadinya, dan juga mau mendengarkan apa yang disampaikan jama'ah thoriqoh. Semakin Gus dianggap berbeda dengan kebanyakan anggota legislatif lainnya membuat Gus seakan-akan bukanlah anggota legislatif yang memiliki kepentingan politik bagi jama'ah thoriqoh. Dengan begitu, jama'ah thoriqoh yang apatis terhadap politik dapat mendukung Gus, karena Gus dianggap bukanlah individu yang bertujuan politik belaka. Pembeda Gus dari kebanyakan anggota legislatif lainnya ini membawa kesamaan atau tingkat homofili yang semakin tinggi antara dirinya dengan kelompok jama'ah thoriqoh. Sebagaimana penelitian Petray (2010) menemukan bahwa strategi diversity atau pembeda dapat meningkatkan homofili yang berdampak pada munculnya dukungan kelompok.

Gus dianggap memiliki kompetensi yang lengkap. Pada satu sisi ia bisa diajak bicara tentang hal-hal yang bersifat keagamaan, sementara di sisi lain ia juga fasih berbicara tentang masalah-masalah kebangsaan. Seperti pernyataan Informan AK "...termasuk urusan haji sedemikian rupa itu sangat positif bagi umat." Selain dapat mengisi ceramah keagamaan, Gus juga dapat menjelaskan permasalahan mengenai sistem Ongkos Naik Haji (ONH) di Indonesia yang dapat dimengerti dengan mudah oleh jama'ah thoriqoh. Dari paparan Gus tersebut jama'ah thoriqoh menjadi paham alokasi dari biaya yang dibayarkan jemaah haji. Gus mampu menjelaskan fenomena yang terjadi di masyarakat dalam konteks nasional. Selain masalah haji, Gus juga mampu menjelaskan soal sertifikasi guru yang seharusnya berdampak pada peningkatan pendapatan guru, namun dalam kenyataannya belum terwujud secara merata. Gus menjalankan fungsi komunikasi politik sebagaimana dinyatakan McNair (2003) yaitu memberikan pendidikan politik terhadap masyarakat tentang arti dan makna dari fakta yang terjadi di masyarakat itu sendiri.

Latar belakang Gus yang berasal dari partai berasas nasionalis tidak dipersoalkan oleh jama'ah thoriqoh, karena bagi mereka yang diutamakan adalah kiprahnya bagi kepentingan bangsa. Gus mendapat dukungan nyata karena tindakan-tindakannya yang dinilai kongkret berpihak bagi perkembangan jama'ah thoriqoh dan masyarakat di daerah pemilihannya. Beberapa informan dalam penelitian ini secara seirama menunjukkan kepercayaan, dukungan, dan kesediaan 
untuk bersikap loyal pada Gus. Bagaimana jama'ah thoriqoh dapat mengesampingkan fakta bahwa Gus merupakan perwakilan dari partai nasionalis dan bukan agamis menunjukkan bahwa tingkat homofili yang dimiliki oleh Gus dan Jama'ah thoriqoh sudah begitu tinggi. Dalam penelitian Opper et al. (2015) juga ditemukan bahwa beberapa aspek kompetensi dapat tidak dihiraukan atau tidak begitu dipentingkan untuk meraih dukungan atau terjalinnya kerjasama jika tingkat homofili yang ada antara satu sama lain sudah tinggi.

\section{KESIMPULAN}

Komunikasi empati dan homofili yang dilakukan oleh Gus kepada jama'ah thoriqoh menimbulkan kredibilitas Gus di mata jama'ah thoriqoh. Gus berkomunikasi dan berperilaku sedemikian rupa sama dengan jama'ah thoriqoh sehingga ia dipersepsikan sebagai bagian dari jama'ah thoriqoh. Ketika ia telah diterima sebagai bagian dari jama'ah thoriqoh, Gus menindaklanjuti dengan komunikasi politik yang fungsinya untuk memberikan pendidikan politik dengan menjelaskan persoalan-persoalan yang terjadi di masyarakat dikaitkan dengan konteks nasional. Komunikasi politik yang dijalankan Gus diterima baik oleh jama'ah thoriqoh, terutama karena Gus dinilai sebagai pribadi yang sederhana, paham persoalan keagamaan dan kenegaraan serta mampu bertindak konkret dengan memberikan dukungan nyata pada perkembangan jama'ah thoriqoh. Persepsi jama'ah thoriqoh terhadap komunikasi empati dan homofili yang dilakukan oleh Gus melalui aspek kesamaan cara berpakaian, agama, bersikap, bertutur kata, dan pelaksanaan ritual menjadikan mereka meyakini pilihan politiknya pada Gus dan memberikan komitmen untuk bersikap loyal.

Temuan penelitian terkait komunikasi empati dan homofili pada kalangan jama'ah thoriqoh memiliki implikasi teoritis. Implikasi teoritis dari penelitian ini ialah sumbangan terhadap konsep homofili. Dari penelitian ini, aspek-aspek pembentuk homofili yang ditemukan meliputi cara berpakaian, agama, cara bersikap, cara bertutur kata, serta sikap dalam menjalankan ritual. Penelitian ini merupakan penelitian yang memiliki limitasi pada kelompok jama'ah thoriqoh sebagai komunikan. Dengan begitu, hasil penelitian berfokus pada sudut pandang komunikan. Untuk penelitian selanjutnya dapat dilakukan penelitian dari sudut pandang komunikator sehingga pengetahuan mengenai komunikasi empati dan homofili dapat terpenuhi dari kedua sisi

\section{DAFTAR PUSTAKA}

Agnew, J., \& Shin, M. (2016). Electoral Dramaturgy: Insights from Italian Politics about Donald Trump's 2015-2016 Campaign Strategy and Beyond. Southeastern Geographer, 56(3), 265272.

Arifin, Anwar. (2011). Komunikasi Politik: Filsafat, Paradigma, Teori, Tujuan, Strategi dan Котиnikasi Poliitik Indonesia. Yogyakarta: Graha Ilmu.

Ariton-Gelan, C. (2015). Ethical Perspectives in the Analysis of Persuasion. Mircea cel Batran Naval Academy Scientific Bulletin, 28(1), 276279.

Basov, N. (2019). The Ambivalence of Cultural Homophily: Field Positions, Semantic Similarities, and Social Network Ties in Creative Collectives. Poetics, (October 2018), 101353. https://doi. org/10.1016/j.poetic.2019.02.004

Bratu, S. (2013). Deconstructing Political Advertising: The Cognitive Processes Underlying Voting Behavior. Journal Geopolitics, History, and International Relations, 5(1).

Carcasson, M., Black, L. W., \& Sink, E. S. (2010). Communication Studies and Deliberative Democracy: Current Contributions and Future Possibilities. Journal of Public Deliberation, 6.

Claassen, R. L. (2011). Political Awareness and Electoral Campaigns: Maximum Effects for Minimum Citizens? Political Behaviour, 33(2), 203223.

Colleoni, E., Rozza, A., \& Arvidsson, A. (2014). Echo Chamber or Public Sphere? Predicting Political Orientation and Measuring Political Homophily in Twitter Using Big Data. Journal of Communication, 64(2), 317-332. https://doi. org/10.1111/jcom. 12084

Egidi, M. (2017). Schumpeter's Picture of Economic and Political Institutions in the Light of a Cognitive Approach to Human Behavior. Journal Evolutionary Economics, 27, 139-159.

Farrell, H. (2012). The Consequences of the Internet for Politics. Annual Review of Political Science, 15(1), 35-52. https://doi.org/10.1146/annurevpolisci-030810-110815

Fouke, D. C. (2009). Democratic Deliberation and Moral Awareness. Journal of Public Deliberation, 5(1).

Galeotti, A. \& Mattozzi, A. (2011). Personal Influence: Social Context and Political Competition. American Economic Journal: Microeconomics, 3, 307-327. 
Gerber, E. R., Henry, A. D., \& Lubell, M. (2013). Political homophily and collaboration in regional planning networks. American Journal of Political Science, 57(3), 598-610. https://doi. org/10.1111/ajps.12011

Housholder, E. E., \& LaMarre, H. L. (2014). Facebook Politics: Toward a Process Model for Achieving Political Source Credibility Through Social Media. Journal of Information Technology and Politics, 11(4), 368-382. https://doi. org/10.1080/19331681.2014.951753

Indrayani, I. I. (2009). Media dan Politik Citra dalam Politik Indonesia Kontemporer. Jurnal Ilmiah Scriptura, 3(2), 129-139.

Koiranen, I., Koivula, A., Keipi, T., \& Saarinen, A. (2019). Shared contexts, shared background, shared values - Homophily in Finnish parliament members' social networks on Twitter. Telematics and Informatics, 36(August 2018), 117-131. https://doi.org/10.1016/j.tele.2018. 11.009

Krause, S. R. (2011). Empathy, Democratic Politics, and the Impartial Juror. Journal Law, Culture and the Humanities, 7(1) 81-100.

Kuppelwieser, V. G. \& Touzani, M. (2016). Attraction During the Dervice Encounter: Examining the Other Side of the Coin. Journal of Services Marketing, 30(5), 504-518.

Maoz, Z. (2012). Preferential Attachment, Homophily, and the Structure of International Networks, 1816-2003. Conflict Management and Peace Science, 29(3), 341-369. https://doi.org/ 10.1177/0738894212443344

McLaughlin, C. M. (2012). Preference for Homophily, Credibility and the Word-of-Mouth Process. Michigan State University: ProQuest.
McNair, B. (2003). An Introduction to Political Communication. London: Routledge.

Mohammad, M. (2007). Perdebatan Hukum Tata Negara Pasca Amandemen Konstitusi. Jakarta: Pustaka LP3ES Indonesia.

Moleong, L. J. (2017). Metodologi Penelitian Kualitatif. Bandung: Rosda Karya.

Moraru, V. \& Rusu, L. (2017). New Media: The Reforming Factor of Political Communication. Journal Communication and Globalization, $7(1)$.

Nahon, K., \& Hemsley, J. (2014). Homophily in the Guise of Cross-Linking: Political Blogs and Content. American Behavioral Scientist, 58(10), 1294-1313. https://doi.org/10.1177/0002764214 527090

Opper, S., Nee, V., \& Brehm, S. (2015). Homophily in the career mobility of China's political elite. Social Science Research, 54, 332-352. https://doi. org/10.1016/j.ssresearch.2015.08.007

Petray, T. (2010). "This isn't a black issue": Homophily and diversity in aboriginal activism. Social Movement Studies, 9(4), 411-424. https://doi. org/ 10.1080/14742837.2010.522309

Plesca, V. (2013). The Crisis of Communication in Democracy. Journal Perspectives on Communication, 3(4), 366-369.

Scudder, M. F. (2016). Beyond Empathy: Strategies and Ideals of Democratic Deliberation. Journal Polity, 48(4), 524-550.

Voicu, C. G. (2013). Communication as Political Discourse: Persuasive Mechanisms and Strategies. Outlook on Communication, 3(3), 210-216. 